\title{
On the High-Standard Trade Rules in the 21st Century and China's Responsive Strategy-A Classical Liberalism Perspective
}

\author{
Chuanfang Zhang \\ Xiamen University Law School, Xiamen, China \\ zhang.chuanfang@qq.com
}

\begin{abstract}
In the nineteenth century, classical liberalism originated from Britain. Nearly all the countries across the globe had benefited from the liberal international economic order (LIEO) under the Pax Britannia. However, the United States has never taken in classical liberalism. Rather, it regards international trade as a "zero sum game" and upholds "fair trade" through the international institution of wTo/GATT. From the British free trade to the U.s. fair trade, from the WTO to the fragmented PTAs, and from free trade to protectionism, classical liberalism has been gradually fading away. The higher standards on the various non-tariff issues in the т Р $\mathrm{P}$ have reached a new altitude against classical liberalism. In face of the high-standard trade rules in the 21st century, China should not follow them recklessly but give due consideration to the status quo of its economic development when negotiating FTAs in the future.
\end{abstract}

\section{Keywords}

LIEO - Pax Britannia - TPP - Pax Americana - China's Response

\section{Introduction}

The current international economic order is undergoing a change and the major economic powers in the world are facing competitions in respect of international economic and trade rules. On 4 February 2016, 12 countries in the Asia-Pacific region including Australia, Brunei Darussalam, Canada, Chile,

(C) CHUANFANG ZHANG, 2018 | DOI 10.1163/23525207-12340030

This is an open access article distributed under the terms of the prevailing CC-BY-NC license at the time of publication. 
Japan, Malaysia, Mexico, New Zealand, Peru, Singapore, the United States and Vietnam signed Trans-Pacific Partnership (TPP) in Auckland. The TPP is a free trade agreement (FTA) led by the United States, which has incorporated the socalled "golden standards". ${ }^{1}$ It has been proclaimed that TPP is in strict consistence with the principle of free trade in which tariffs are reduced to zero. Not only various non-trade issues such as intellectual property rights (IPRs), labor rights and environmental protection were added to the TPP, but the protection offered by these rules was even higher than that of the previous FTAs signed by the United States. One conspicuous feature concerning the TPP is that China and many other countries in this region were excluded from the negotiations. The United States attempts to let other countries play by the rules that America and its partners set. Thus, as a Pacific power, it pushed to develop a high-standard ТРP, a trade deal that makes sure "the rules of the road for trade in the 21st century are written by the United States", rather than by China. ${ }^{2}$

On January 23, 2017, the U.S. President Donald Trump "unravelled the Trans-Pacific Partnership, withdrawing the us from the controversial freetrade pact". ${ }^{3}$ Thereafter, Japan took over and launched the negotiations of the Comprehensive Progressive Trans-Pacific Partnership, CPTPP. No matter what name it adopts, the "golden standards" embedded in the TPP represent a trend of the trade rules in the 21st century and deserve further study. This article attempts to offer a critical analysis of several high-standard trade rules in the TPP agreement from the perspective of classical liberalism and give some suggestions on China's responsive strategy. In Part 1 of this article, the author tries to give a brief historical review of the evolution of the Liberal International Economic Order (LIEO). Part 2 illustrates how the "golden standards" in the TPP agreement contradict classical liberalism and why they were coined anyway. On the basis of the analyses in Part 1 and Part 2, suggestions on how China should respond to the high-standard rules and classical liberalism are given in Part 3 followed by conclusions.

1 "Golden standards" means the high standards incorporated in the TPP on the protection of intellectual property rights, labor rights and environment.

2 UStr Press Release, President Obama: The TPP would let America, not China, lead the way on global trade, May 2, 2016, at https://ustr.gov/about-us/policy-offices/press-office/press -releases/2016/may/cross-post-president-obama-tpp-would, accessed on May 16th, 2016.

3 Trump signs executive order withdrawing Us from TPP, Prokerala News, January 23, 2017, at http://www.prokerala.com/news/articles/a712367.html (last visited on March 8, 2017). 
Deepak Lal upholds the view in his book In Praise of Empires-Globalization and Order that the public good of international peace is needed to maintain global trade and business, and that such public good is often proffered by one hegemon. In much of the human history, this kind of public goods was in fact provided by the imperium. ${ }^{4}$ In total, there have been two LIEOs in the history of mankind. One is the nineteenth-century LIEO created by the United Kingdom under the Pax Britannia. ${ }^{5}$ The other is the modern LIEO led by the United States under the Pax Americana. ${ }^{6}$

\subsection{LIEO under the Pax Britannia}

After the Glorious Revolution in 1688, the British established a fiscal-military state. This government provided impetus for the "gentlemanly capitalism"7 emerged in the eighteenth century and expanded the geographical reach for British trade and commerce. Through sustained armed force and skillful diplomacy, the British defeated its primary rivals Spain and Portugal, especially The Netherlands and France, thus maintained its economic benefits. ${ }^{8}$ In the eighteenth century, with its industrialization, Britain waged continual wars with its continental rivals. It took Britain nearly a century from the conflict with France in the mid-eighteenth century to the end of the Napoleonic War to gain a relative advantage. After Napoleon's failure at Waterloo, Britain became the largest global empire to that date. ${ }^{9}$

Prior to 1820 , most commodities in most countries are non-tradable. This was partly due to the high costs of international transportation, but also

4 See Deepak Lal, In Praise of Empires-Globalization and Order, Palgrave-Macmillan, New York, 2004.

5 "Pax Britannia" lasted from Napoleon's failure at Waterloo till the end of the 19th century.

6 "Pax Americana" refers to the relative peace maintained by the U.s. preponderance in power from the middle of the 2oth century till present. From mid-1940s to 1991, the U.s. foreign policy was dominated by "Cold War" which features the U.s. military forces and diplomatic engagement across the world. Therefore, "Pax Americana" is just part of the international order and it cannot represent the global order as a whole because it only applies to the capitalist countries. See Joseph S. Nye, Jr., The Changing Nature of World Power, Political Science Quarterly, The Academy of Political Science, Vol. 105, No. 2 (Summer, 1990), at 177-192.

7 See Cain P.J. and A.G. Hopkins, British Imperialism 1688-2000, Longman, London, 2002.

8 See O'Brian P.K., Inseparable Connections: Trade, Economy, Fiscal State and the Expansion of Empire, 1688-1815, in P.J. Marshall (ed.), The Oxford History of the British Empire, Vol. 2: The 18th Century, Oxford University Press 1998, at 71.

9 See Deepak Lal, Reviving the Invisible Hand: the Case for Classical Liberalism in the TwentyFirst Century, Princeton University Press 2006, at 21. 
because all the countries imposed strict restrictions on imports in times of mercantilism. The consequence was that the prices of most commodities produced in different countries had huge divergences. ${ }^{10}$ The British repealed the Corn Laws in 1846 and then adopted the unilateral policy of free trade, which marked the beginning of the first LIEO under the leadership of Britain. ${ }^{11}$ During the half century thereafter, free mobility of goods, capital and labor had been truly realized. ${ }^{12}$ For the first time in the history of mankind, all the economies across the globe had been truly interconnected through the international trade of goods, which marked the beginning of the first globalization. ${ }^{13}$ In spite of the boycott of this inexorable trend, the British had largely maintained the policy of free trade till the Great Depression in $1931 .{ }^{14}$

\subsubsection{Pillars of the British LIEO}

There were three pillars for the nineteenth-century LIEO under the leadership of the United Kingdom: free trade, gold standard and international property rights..$^{15}$ These three pillars supported each other and constituted the features of classical liberalism. ${ }^{16}$

\section{Free Trade}

The first pillar of the LIEO under Pax Britannia was free trade. Britain had by the end of the eighteenth century not been an agricultural economy. ${ }^{17}$ Britain had gained far more benefits from free trade than agriculture and the repeal of Corn Laws just echoed the decline of its agricultural economy. Moreover, the climate of public opinion was shifted by the thoughts of the British economists, from the support for mercantilism to that for classical liberalism and free trade. ${ }^{18}$ However, the unilateral policy of free trade adopted by Britain was not imitated by other countries. In 1860, Napoleon III concluded the Cobden-Chevalier Treaty with Britain. Owing to the fact that the trade agreements concluded by France with other European countries all incorporated the M FN provision, the

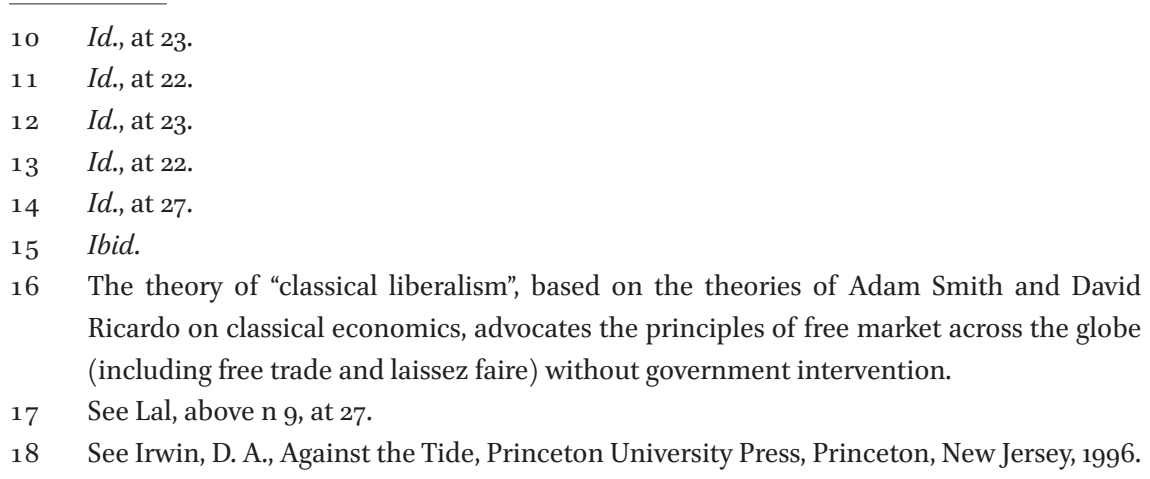


network of these trade agreements resulted in ubiquitous tariff concessions and de facto free trade between European countries from 1860 s to $1870 .^{19}$

\section{Gold Standard}

As the leading economic, political and commercial power in the world to that date, Britain adopted the monetary system of gold standard. It thus became the international monetary system around 1870 and served as the second pillar of the nineteenth-century LIEO. Due to Britain's ascendant position in trade and capital circulation, most countries chose to follow Britain's practice. This was an example for emulation of the successful. ${ }^{20}$ However, with the rise of demos, domestic political features as the base of the gold standard collapsed and this kind of monetary system was doomed to fall.

\section{(3) International Property Rights}

The third pillar for the nineteenth-century LIEO was the transnational legal system. The purpose of this legal system was to protect property rights, especially those of foreigners. The commercial treaties concluded by the European countries in the mid-nineteenth century included rules concerning protection of international property rights. These rules had finally been strengthened as the general principles of international law. ${ }^{21}$ The economic and property rights of foreigners had been further strengthened by the Treaty of Westphalia (1658) and the Treaty of Paris (1763). This process peaked in the nineteenth century "with the security of foreigners and their property guaranteed by every European state, by the United States soon after its independence, and by the new Latin American states after their wars of independence." 22

\subsubsection{Economic Development under the British LIEO}

The three pillars of the British LIEO made the global expansion of trade and commerce possible. The free trade policy largely reduced the tariffs. The gold standard integrated the international payment system. Unified legal system lowered the costs of international trade. Under the British LIEO, the

19 See Conybeare J.A.C., Leadership By Example? Britain and the Free Trade Movement of the nineteenth century, in Bhagwati (ed.) Going Alone, MIT Press, Cambridge, Mass., 2002.

20 See Lal, above n 9 , at 30.

21 Lipson C., Standing Guard, University of California Press, Berkeley, 1985, at 8. Lipson notes that these principles were: "foreigners were deemed subject to local laws, as they had been since the Middle Ages, but national jurisdiction over aliens and their property had to comply with a variety of international standards". 
nineteenth century had experienced such a trade mode: ${ }^{23}$ "the 'North'mainly western Europe-specialized in the new industrial products and experienced Promethean intensive growth, ${ }^{24}$ while the 'South' — which included the current Third World and the areas of 'new' settlement in the Americas and Australasia - specialized in primary products and experienced Smithian intensive growth."25

The British LIEO reached its culmination between the period of 1850 and 1914, during which many developing countries in the third world had experienced sustained intensive economic growth for the first time. Lloyd Reynolds, in his survey of the economic histories of 41 developing countries, picked the climacteric date watersheding the extensive growth (with a sustained rise in per capita incomes) and the intensive growth (when output growth just kept up with that of population) of these developing countries. ${ }^{26}$

\subsubsection{The End of the British LIEO}

The British LIEo created in the nineteenth century did not last in the twentieth century. The starting of the First World War marked the end of the first LIEO.$^{27}$ In much of the nineteenth century after Waterloo, international peace had been provided by the direct and indirect empire of Britain policed by its Royal Navy. However, by the end of the nineteenth century, the British economic ascendancy and its military power as a complement had slipped with the rise of the United States and Germany. ${ }^{28}$ In fact, by the end of the nineteenth century, the United States had already replaced Britain as the world's leading economic power.

The United States, during the Great Depression resulting from its faulty monetary policy and its protectionist trade policy, ${ }^{29}$ failed to do what Britain in

23 This "colonial" international division of labor has been the target of economic nationalists in the South ever since. Id., at 15 .

24 "Promethean growth" means the leap-style economic growth caused by technology revolution. Prometheus is a god in Greek mythology who taught humans to use fire which marks a leap-style revolution in the history of human civilization.

25 "Smithian growth" originated from Adam Smith who believes that economic growth depends on the increase of productivity and the expansion of the market, which are the results of labor division and specialization.

26 Reynolds L.G., Economic Growth in the Third World, Yale University Press, New Haven, 1985 , at 958 .

27 See Lal, above $\mathrm{n}$ 9, at 38 .

28 Ibid.

29 The causes of the Great Depression are still being hotly debated by scholars. However, most agree that it was caused by domestic and international monetary factors. 
the depression of the 187os had done: to maintain open markets for trade and finance. ${ }^{30}$ The Smoot-Hawley Tariff and Blue-Sky Laws enacted by the United States during the interwar prohibited u.s. banks from lending to foreign governments, and this put an end to the LIEO on a factual basis. ${ }^{31}$ Even worse than that, the complicated network of international law and practice the British had woven in the nineteenth century to protect foreign capital had also been unraveled during the interwar period. The decline of the British power as a hegemon made the enforcement of the international rules created in the nineteenth century full of problems. ${ }^{32}$ Even though the U.s. economic interests continued to expand, it still refused to undertake relevant political and military responsibilities outside the western hemisphere. Britain's shrunken power and the U.s. isolationism had weakened the capability of developed capitalist countries in strengthening the international rules for property rights. ${ }^{33}$

\subsection{LIEO under the Pax Americana}

After the Second World War, the United States attempted to restore the three pillars of the nineteenth-century LIEO through the Bretton Woods system, namely free trade, gold standard and free mobility of capital. However, the socalled LIEO created under the leadership of the United States diverged largely from that of Britain. Unlike Britain establishing the three pillars through treaties and direct and indirect imperium, the United States created some transnational institutions, such as the General Agreement on Tariffs and Trade (GATT), which was succeeded in 1995 by the World Trade Organization (WTO), the International Monetary Fund (IMF) and the World Bank (WB). These institutions were based on neo-liberalism. ${ }^{34}$ Under the American LIEO, the United States did not implement the policy of free trade..$^{35}$

3o See Kindleberger C.P., The World in Depression, 1929-39, University of California Press, Berkeley, 1973.

31 See Lal, above n 9, at 39 .

32 Ibid.

33 Lipson C., Standing Guard, University of California Press, Berkeley, 1985, at 66.

34 "Neo-liberalism" refers to the revival of the 19th-century economic liberalism featuring laissez faire in the 2oth century. The notions of "neo-liberalism" include extensive policies on economic liberalization such as privatization, fiscal austerity, government deregulation, free trade and public-spending cutting to strengthen the role played by private sectors. See Taylor C. Boas, Jordan Gans-Morse, Neoliberalism: From New Liberal Philosophy to Anti-Liberal Slogan, Studies in Comparative International Development, Vol. 44, 2009, No. 2, 137-161. However, the above measures left room for various degrees of government intervention.

See Lal, above n 9, at 40. 


\subsubsection{The U.S. LIEO}

The two pillars of the Great Britain's domestic policies were laissez faire and unilateral adoption of free trade, both of which were in conformity of classical liberalism. ${ }^{36}$ However, the United States, though in favor of laissez faire and free trade vocally, never consistently enforced these policies domestically.

\section{From Laissez Faire to Dirigisme}

At the end of the nineteenth century, the federal government of the United States was smaller than that of Britain in scale. The size of the United States' government was small until 1920s. The Great Depression in 1920s and Roosevelt's New Deal were the critical moment for the expansion of government and the abandonment of laissez faire. Roosevelt's New Deal caused "an ideological shift-from widespread skepticism about the ability of the central government to improve the functioning of the economy to widespread faith in the competence of government." ${ }^{37}$ It was from that moment when the share of the U.S. government expenditure in GDP expanded drastically. ${ }^{38}$

\section{From Free Trade to Protectionism}

Unlike Britain, the United States failed to adopt the unilateral policy of free trade and then to extend this policy to other countries through its hegemony. The U.S. practice is to lower tariffs by acrimonious multilateral negotiations within GATT/WTO. The reason why the United States refuses to follow the approach of unilateral free trade is that the Americans have never accepted the economic theory of classical liberalism, but rather regards trade as a "zero sum game". ${ }^{39}$ In the U.S. perspective, its adoption of free trade is nothing short of concessions in favor of other countries, which is impossible if it cannot obtain the same concessions in return.

The instinct attitude of the United States towards international trade has been protectionist. The earliest argument for protectionism is the "Infant Industry Protection" provided by Hamilton. ${ }^{40}$ The United States had, by the end of the nineteenth century, already realized industrialization and accumulated

$36 \quad$ Id., at 48 .

37 Rockoff H., By Way of Analogy: The Expansion of the Federal Government in the 1930's, in Bordo, Goldin and White (eds.), The Defining Moment, University of Chicago Press, Chicago, 1998, at 125 .

38 See Lal, above n 9, at 65 .

$39 \quad I d$., at 41.

$40 \quad$ For the flaws of the "Infant Industry Protection", see Baldwin R.E., The Case Against Infant-Industry Tariff Protection, Journal of Political Economy 77 (May/June), at 295-305. 
lots of capital and technology. Its comparative advantage had already shifted from land-intensive products to technology-intensive goods, but the protectionism has never been shaken. The U.s. Constitution grants its Congress the power to levy taxes and to regulate international commerce, thus making the interplay between the U.s. interest groups the dominant factor in the formulation of the U.s. trade policy. ${ }^{41}$ Later, in his 1901 State of Union Address, Roosevelt established the principle of reciprocity as the core principle of the U.s. trade policy.

\subsubsection{The U.s. Fair Trade}

The U.s. Congress in 1934 enacted the Reciprocal Trade Agreements Act (RTAA).the basic principle of RTAA was reciprocity which was incorporated into GATT after the Second World War. The United States, the hegemon in the twentieth century sought to achieve free trade through mutual concessions within WTO and its predecessor GatT. ${ }^{42}$ In the early 1980 s, the United States gradually shifted away from the multilateral trade policy through GATT to the so-called "aggressive unilateralism" and preferential trading arrangements (PTAS).

Aggressive Unilateralism

The United States has, since 1970s, been pursuing aggressive unilateralism to combat the unfair trade of other countries. In the U.S. perspective, it is the only fair trader and all its trading partners are conducting unfair trade. ${ }^{43}$ In 1974, the U.s. Trade and Tariff Act was passed. This Act not only granted the United States the power to retaliate its trading partners that infringed the U.s. benefits within the framework of GATT and bilateral agreements, but also conferred upon the U.s. President the power to take actions outside those frameworks to counter the "unreasonable" trade behaviors. It actually authorized the U.s. government to blackjack all the countries that may be against its will. However, this Act was repealed in the end. The reasons are as follows. First, the establishment of the Dispute Settlement Mechanism of the Wто makes the unilateral threat to those defaulting countries unnecessary. Second, because Section 301 was bullying, the што made a decision forbidding the United States to force other countries to make new concessions by using this Act. ${ }^{44}$

\footnotetext{
41 See Lal, above $\mathrm{n} 9$, at 67.

$42 \quad I d$. , at 41.

43 Id., at 75 .

44 Ibid.
} 
(2)

\section{The Rise of PTAS}

Primarily due to the slow progress of multilateralism, the United States has gradually turned to bilateral and regional free trade agreements (FTAs) since 1980s. ${ }^{45}$ After the successful negotiation of Tokyo round, the EU and some major developing countries (India and Brazil) refused to launch the next GATT round. In face of this frustration, William Brock, the U.S. Trade Representative, proposed a "twin-track" approach: if the multilateral progress of free trade was blocked, the United States would liberalize trade through PTAs with its likeminded partners. ${ }^{46}$

PTAs are the enemies of the multilateral trading system ${ }^{47}$ because any preferential arrangement will bring about new interest groups created by trade diversion, and these interest groups will obstruct the progress of multilateral trading system. ${ }^{48}$ PTAs can also increase the costs of regulatory cooperation for all trading partners. To protect the preferences granted to partners, PTAs design complicated "rules of origin" to prevent non-members from exporting goods to partners with high external trade barriers through those with lower ones. ${ }^{49}$ Whilst the countries excluded from a preferential arrangement establish their own PTAs with other countries, the quantity of PTAs will increase drastically, leading to what is called a "spaghetti bowl". ${ }^{50}$ This will not only multiply the regulatory costs for partners, but also cause the de facto destruction of the multilateral trading system. ${ }^{51}$

\section{Social Policies}

The spanner of "faire trade" has offered various pretenses for multifarious protectionist lobbying groups which create huge impact on the U.s. trade policy. These lobbying groups would accuse the U.s. trading partners for their unfair social policies concerning labor rights and environmental protection, trying to spread the high U.S. social standards to the whole world by way of

$45 \quad I d$. , at 71 .

$46 \quad I d$., at 74 .

47 For the threats to the multilateral trading system, see Bhagwati J., Free Trade Today, Princeton University Press, Princeton, New Jersey, 2002; see also Irwin D.A., Free Trade Under Fire, Princeton University Press, Princeton, New Jersey, 2002.

48 See Lal, above n 9, at 72 .

49 See Krueger A.O., Free Trade Agreements as Protectionist Devices: Rules of Origin, in J.R. Melvin, J.C. Moore, and R. Reizman (eds.), Trade, Theory and Econometrics, Routledge, New York.

50 See Snape R., Trade Discrimination? Yesterday's Problem?, Economic Record 72, 219 (December): $381-96$.

$5^{1} \quad$ See Lal, above $\mathrm{n} 9$, at 72 . 
WTO/GATT. In the 1970s, under the pressure of trade unions, the U.s. Congress incorporated into the Trade Act 1974 a provision requiring the president to put forward the subject of "fair labor standards" in the GATT framework. In October of 1979, President Jimmy Carter performed this obligation prior to the completion of the Tokyo round. ${ }^{52}$ In 1980, while the Multi-Fiber Agreement (MFA) was being renewed, organizations representing manufacturers and workers in textiles and clothing industries in the United States and western Europe proposed an addition of "social clauses" to the MFA..$^{53}$ Incorporating non-trade issues such as labor and environmental protection into the WTO is to promote protectionism which is against classical liberalism.

\subsection{Preliminary Conclusions}

In the nineteenth century, classical liberalism originated from Britain. The British correctly recognized that free trade was beneficial both to themselves and to others at the same time. Under the circumstances where mercantilism and high tariffs were in vogue, Britain was the first to adopt the policy of unilateral free trade. No matter how its trade partners obstructed free trade, Britain still unilaterally lowered its tariffs in a large scale and even removed some of its tariffs completely. Nearly all the countries across the globe had benefited from the LIEO under the Pax Britannia, and the world economy had obtained substantial development.

After the two World Wars, Britain was on the wane and the United States has become the leading power in the world. Ostensibly, the United States has inherited Britain's free trade policy; but in fact it has never taken in the essence of classical liberalism. Rather, it regards international trade as a "zero sum game" and upholds "fair trade" through the international institution of wто/ GATT. Primarily due to the slow progress of multilateralism, the United States has since 1980 os gradually turned to bilateral and regional free trade agreements (FTAS). Under the spanner of "fair trade", various non-tariff issues on social policies have offered pretenses for protectionism. From the British free trade to the U.s. fair trade, from the Wто to the fragmented PTAs, and from free trade to protectionism, classical liberalism has been gradually fading away, which reflects the receding of the dominant power of the world's hegemon.

$\begin{array}{ll}52 & \text { Id., at } 76 . \\ 53 & \text { Id., at } 77 .\end{array}$ 


\section{The High-Standard Trade Rules in TPР-A New Altitude against Classical Liberalism}

TPP is labeled as a group of like-minded countries negotiating a high-standard free trade agreement in the 21st century. The United States has played a crucial role in the negotiation of the TPP, for which we can say TPP is an FTA reflecting the U.s. priority and values in the Asia-Pacific area. "The TPP not only seeks to provide new and meaningful market access for American goods and services exports, but also set high-standard rules for trade, and address vital 21st-century issues within the global economy."54 The United States proclaims that the TPP will support Made-in-America exports, enforce fundamental labor rights and promote strong environmental protection. The so-called "golden standards" in the TP P has reached a new altitude against classical liberalism. In this part, the author attempts to analyze some of the "golden standards" in the TPP agreement and find out the possible reasons why they have been coined anyway.

\subsection{Intellectual Property Rights}

The wTo Agreement on Trade-Related Aspects of Intellectual Property Rights (TRIPS) provides the basics for the protection of intellectual property, including minimum standards of protection and enforcement procedures for related infringements. ${ }^{55}$ TP P has included various "TRIPS-plus" provisions that establish higher standards for protection of intellectual property than TRIPS, extend protection to a broader array of intangible property, and lower flexibilities established in TRIPS.

In comparison with TRIPS, TPP has offered higher standards of protection for copyright and related rights. Here are some examples. In Article 18.63, the term of protection for copyright and related rights has been extended from 50 years in TRIPS to 70 years. ${ }^{56}$ In order to protect its medicine industry, the United States attempted to make the period of protection for new data of

54 USTR, Trans-Pacific Partnership (TPР): Unlocking Opportunity for Americans through trade with the Asia Pacific, at https://ustr.gov/trade-agreements/free-trade-agreements/ trans-pacific-partnership, accessed on July 1oth, 2016.

55 See Gary Clyde Hufbauer and Cathleen Cimino-Isaacs, How will TPP and тTIP Change the wто System?, Journal of International Economic Law, Vol. 18, 2015, at 691.

56 Text of Trans-Pacific Partnership Agreement, Chapter 18 Intellectual Property, Section H: Copyright and Related Rights, Article 18.63: Term of Protection for Copyright and Related Rights. 
pharmaceutical products 12 years. However, under the pressure of Japan and other countries' opposition, the protection period has been set at 5 years. ${ }^{57}$

In an effort to better reflect the realities of the "new digital economy", new provisions relating to trade secrets ${ }^{58}$ and internet service provider ${ }^{59}$ have been incorporated in TPP. Provisions on trade secrets are positioned under Section I (Enforcement). In Paragraph 1 of Article 18.78 provides: “... As used in this Chapter, trade secrets encompass, at a minimum, undisclosed information as provided for in Article 39.2 of the TRIPS Agreement." This indicates that the coverage of trade secrets is not limited to those stipulated in Article 39.2 of TRIPS, but subject to expanding interpretation. The fact that the provisions on trade secrets are placed under the section of enforcement shows that trade secrets have been given robust protection because they are guaranteed by enforcement provisions. In the TPP text, provisions on internet service provider have been put in a separate section, with the "Definitions" of internet service provider stipulated in Article 18.81 and "Legal Remedies and Safe Harbours" in Article 18.82. Where copyright is infringed online, the right holder may get proper legal remedies against the infringing parties, while the internet service provider can obtain impunity under the "Safe Harbours" provisions.

The flexibilities of the TPP members' governments in determining what is patentable have been severely eroded. In the TRIPS Agreement, important flexibilities are included for governments to decide what type of pharmaceutical products deserves to be protected by patents in a given country. Essential requirements such as "novelty", "inventive step", and "industrial applicability" can be defined by lawmakers in different countries so that they are appropriate within the context of national circumstances. ${ }^{60}$ However, the TPP has severely limited the ability of each country to define what is patentable. In Article 18.37 of the TPP text, patentable subject matters are provided. A party cannot exclude an exploitation from patentability merely because it is prohibited by its law. Exclusion of patentable inventions can be made only when it is necessary to "protect ordre public or morality, including to protect human, animal or plant life or health or to avoid serious prejudice to nature or the environment". ${ }^{61}$

57 Id., Subsection C: Measures Relating to Pharmaceutical Products, Article 18.50: Protection of Undisclosed Test or Other Data, Para. 1(a).

58 Id., Article 18.78 Trade Secrets.

$59 \quad I d$., Section J: Internet Service Providers.

6o See Ming Du, Explaining China's Tripartite Strategy Toward the Trans-Pacific Partnership Agreement, Journal of International Economic Law, Vol. 18 (2015), No. 2, at 421.

61 Above $\mathrm{n}$ 56, Section F: Patents and Undisclosed Test or Other Data, Subsection A: General Patents, Article 18.37: Patentable Subject Matter. 
The "TRIPS-plus" provisions in the TPP agreement will lower the welfare of the developing members of the TPP. The IPRs issue has been a contentious area in the negotiations of the TPP, due to differences among TPP partners on appropriate levels of obligations in patent rights for pharmaceuticals, copyright terms, and enforcement mechanisms. ${ }^{62}$ Concerns on pharmaceuticals and biologics put the question of whether high standards of IP Rs protection are necessary to the spotlight. It is true that powerful provisions on IPR protection are helpful for incentivizing innovation, but these provisions may also block the access of the poor developing countries to medicines. These developing countries cannot afford the high prices of the medicines used to fight against such diseases as HIV/AIDS. As a whole, the increased IPRs protection required by the TRIPS component of the Uruguay Round bargain resulted in welfare losses to developing countries. Different from the reciprocal tariff concessions, TRIPS causes an effect that the benefits are purely transferred from the developing countries to the hands of the manufacturers in developed countries. ${ }^{63}$ Globally, developing countries have made huge sacrifices by accepting the TRIPS in the Uruguay Round negotiations, while the United States attempted to only enjoy privileges, but refused to fulfill its obligations by raising the standards on various non-tariff issues so as to rob the developing countries of their jobs in the manufacturing.

There's an important question about what lies behind the U.s. intent to incorporate into TPP higher standards for IPRs protection than TRIPS. In the information age, the advancement of science and technology has changed the pattern of international division of labor: the "North" countries mainly engage in highly-skilled intellectual jobs; the low-and semi-skilled jobs are undertaken by the "South" countries in Asia; and the natural resource-rich countries of Africa and Latin America specialize in the production of primary commodities. ${ }^{64}$ According to David Ricardo's Theory of Comparative Advantage, every country should manufacture and export products with comparative advantage while importing those with comparative disadvantage. The U.s. advantageous endowment lies in the research and development of high technology. In contrast, its manufacturing industry has no advantage in the global production chain. Thus, masses of job opportunities in manufacturing have been transferred to developing countries where the labor costs are relatively low. Globalization has resulted in losses for the unskilled workers in the "North" countries such as America, whose existence in large quantity has

\footnotetext{
62 See Hufbauer and Isaacs, above n 55 , at 691.

63 See Lal, above n 9 , at 88.

64 Id., at 232.
} 
failed to adapt the "North" countries to the newly emerged international division of labor.

The U.s. upper class represents the high-tech R\&D and capital which serves as the impetus of globalization. They prompted the U.s. government to incorporate the IPR issues in the Uruguay round of WTO trade negotiations. In terms of the strengthening IPRs protection, TPP has synchronized with globalization and catered to the interests of the upper class. However, the U.s. middle class will not benefit from TPP directly, but rather will suffer from job losses caused by the deepening of globalization which will further widen the interest gap between the U.s. upper and middle class. The middle class attempts to use political processes to resist the newly emerged international division of labor ${ }^{65}$ and globalization at large in hopes of getting their jobs back which constitutes their instinctive response. The Office of USTR proclaims that: "the TPP will make it easier to sell Made-in-America goods and services exports to some of the most dynamic and fastest growing markets in the world, and support homegrown jobs and economic growth."66 It is doubtful whether this goal can be achieved. TPP's forging ahead of Made-in-America is against the trend of international division of labor becoming increasingly thinning and specialized in times of globalization. The dream of "Made in America" is more of a slogan soothing the bleeding heart of the middle class. However, the middle class had not bought this "cake" prepared by the Democratic President Obama, and that explains in large part why Trump, a Republican President, had scrapped тPР.

\subsection{Labor Rights}

The issue of trade and core labor standards has been the subject of intense debate among the governments of the World Trade Organization members for many years. A number of developed countries suggested that the issue be brought into the Wто through the formation of a working group to study the issue of trade and core labor standards, believing that this will provide incentives for WTO member governments to improve the conditions for workers across the globe. However, most developing countries and many developed nations believe that this issue does not belong to the WTO, regarding the issue of trade and labor standards as a guise for protectionism in developed-country

65 Ibid.

66 USTR, Trans-Pacific Partnership (TPP): Unlocking Opportunity for Americans through trade with the Asia Pacific, at https://ustr.gov/trade-agreements/free-trade-agreements/ trans-pacific-partnership, accessed on July 1oth, 2016. 
markets and a smokescreen for undermining the comparative advantage of lower-wage developing countries. ${ }^{67}$

In the interests of the U.S. middle class, the labor rights provisions in WTO are nothing but pretenses for the United States to pursue protectionism. These provisions may make free trade impossible because the potential benefits resulted from low tariff rates between the WTO members may well be offset by the high labor standards. Neither developing countries nor developed countries will benefit from these provisions. Owing to the fact that the high labor standards will weaken the comparative advantage of developing countries, they are extremely concerned about the effects of these labor standards on their economic development. Attaching this non-tariff issue of labor rights to TPP will not only be unable to achieve the goal of protecting the benefits of workers, but also could make worse the economy in developing countries. ${ }^{68}$ For developed countries, these labor standards are the determinant factors for the slow-down of the economic development in the United States and the European countries. In terms of "elimination of discrimination in respect of employment and occupation", the enterprises in developed countries have even been driven to the situation of being unable to freely choose their employees. In respect of "no derogation or reduction of labor rights", the real condition has developed into the enterprises being unable to lower the wages of their employees no matter how difficult their business operation has become. Thanks to these provisions, these enterprises have become reluctant to employ new workers, which constitutes the direct reason of high unemployment rate.

The office of USTR proclaims that: "the TPP will level the playing field for American workers and businesses by building strong and enforceable labor standards." ${ }^{69}$ In the chapter 19 of the TPP texts stipulates the following internationally recognized labor rights: (a) freedom of association and the effective recognition of the right to collective bargaining; (b) the elimination of all forms of forced or compulsory labor; (c) the effective abolition of child labor; and (d) the elimination of discrimination in respect of employment

67 Trade and Labour Standards: Subject of Intense Debate, World Trade Organization, available at https://www.wto.org/english/thewto_e/minist_e/ming9_e/english/about_e/ 18lab_e.htm, accessed on July 15th, 2016.

68 Robert M. Stern and Katherine Terrell, Labour Standards and the World Trade Organization, A Position Paper (August 2003), at http://www.fordschool.umich.edu/rsie/ workingpapers/Papers476-50o/r499.pdf, accessed on August 5th, 2016.

$69 \quad$ Ibid. 
and occupation; (e) acceptable conditions of work with respect to minimum wages, hours of work, and occupational safety and health. ${ }^{70}$

In the TPP, the central issue with respect to labor rights is not the content of the ILO Declaration, but rather how the obligations will be enforced. In the negotiations of the TPP, the Americans pointed out that the us Congress would not accept a TPP without powerful enforcement provisions on labor standards. Some congressional Democrats, echoing the AFL-CIO (American Federation of Labor and Congress of Industrial Organizations), urge that the TPP should enforce labor rights through an arbitration mechanism, and that trade unions should have standing to bring cases. However, this seems most unlikely: neither USA nor its TPP partners want to confer on arbitration panels the power to interpret the four broad principles enunciated in the ILO Declaration. Countries have their own courts and administrative panels for enforcing labor legislation and they adamantly oppose intrusion by international panels in this sensitive area. ${ }^{11}$ This is substantiated by the texts of the TPP. In Article 19.15 refers to stateto-state consultations and dispute settlement concerning labor standards. If the consulting Parties have failed to resolve the matter no later than 60 days after the date of receipt of a request under paragraph 2, the requesting Party may request the establishment of a panel under Article 28.7 (Establishment of a Panel) and, as provided in Chapter 28 (Dispute Settlement), thereafter have recourse to the other provisions of that Chapter. ${ }^{72}$ No Party shall have recourse to dispute settlement under Chapter 28 (Dispute Settlement) for a matter arising under this Chapter without first seeking to resolve the matter in accordance with this Article. ${ }^{73}$ Moreover, the trade unions are not conferred upon the right to bring cases. The parties to the TPP would be obligated to adopt, implement, and effectively enforce laws and regulations to fulfill their obligations that are contained in the ILO Declaration on Fundamental Principles and Rights at Work and Its Follow-Up. These provisions are enforceable under dispute settlement provisions of the TPP and violations are subject to potential trade sanctions.

As to the reasons why the Obama administration would reinforce the labor rights protection in the TPP, the U.S. trade unions as representatives of the middle class played an important role. In order to secure their jobs, the middle class would use the domestic political processes to influence the U.s. foreign trade policy, and use the U.s. dominant power in the international economic

\footnotetext{
70 Text of Trans-Pacific Partnership Agreement, Chapter 19 Labour, Article 19.1 Definitions.

71 See Hufbauer and Isaacs, above $\mathrm{n} 55$, at 683 .

72 Above n 70, Article 19.15 Labour Consultations, para. 12.

73 Id., Article 19.15 Labour Consultations, para. 13.
} 
order to shift the pressure of job losses to developing countries. The U.s. trade unions have a command of many votes. If congressmen plan to obtain the votes of trade unions, they must help them suppress competition from workers in other countries, even though they are fully aware that this would run counter to globalization and the U.s. consumers' benefits are also at stake. The United States has been apt to wield the big stick of "trade sanctions" at every turn, but in most cases its actions are under the abduction of the middle class. ${ }^{74}$ It is common sense among the upper class and the political elites in the United States that "trade sanctions" are bad for free trade, but limited to votes politics, congressmen have to concede to trade unions. However, it is doubtful that higher standards of labor rights protection would relocate the jobs in manufacturing back to America, and adverse effects may instead arise on the U.S. economy. On another note, the fact that the trade unions have not been conferred upon the right to bring cases illustrates that the political elites in the United States have not been fully abducted by the middle class and trade unions. On labor rights protection, TPP may be "all hats and no cattle". This may be another reason why TPP was abandoned by the Trump administration.

\subsection{Environment Protection}

Environment organizations have always been trying to hijack the wTo to achieve its own objectives and they have played a significant part in incorporating environmental issues into WTO. These organizations excel at advocating its own ideas under the spanner of public good which is a time-tested persuasive argument. In prompting the TPP negotiations, the Office of USTR proclaims that: "Environmental protection is a core American value. Through the TPP, the United States is negotiating for robust environment standards and commitments from member countries, and addressing some of the region's most pressing environmental challenges. ${ }^{\prime 75}$ In Chapter 20 (Environment) of the TPP agreement, there are 23 articles dilating upon environment-related matters among the member states, which reflect the aspirations of the negotiating parties in forging a high-standard trade agreement in terms of environment. Next, this paper will select several aspects in the TPP environment chapter to examine how environment organizations will affect trade liberalization.

\footnotetext{
74 Since Obama assumed office in January 2009, the United States has initiated 12 cases against China in wто. See https://www.wto.org/english/tratop_e/dispu_e/find_dispu_ cases_e.htm\#results. The frequent lawsuits can be construed as the U.s. intention of shifting the contradiction between the U.s. upper and middle class away to China.

Above $\mathrm{n} 66$.
} 
The objectives of this Chapter are to promote mutually supportive trade and environmental policies; promote high levels of environmental protection and effective enforcement of environmental laws; and enhance the capacities of the Parties to address trade-related environmental issues, including through cooperation. ${ }^{76}$ Despite the fact that the sovereign right of the contracting parties to establish their own levels of domestic environmental protection, the parties shall be committed to the obligation of ensuring that their environmental laws and policies provide for and encourage high levels of environmental protection, and continuing to improve its respective levels of environmental protection. ${ }^{77}$ In paragraph 4 of Article 20.3 of the TPP text, it provides that "no Party shall fail to effectively enforce its environmental laws through a sustained or recurring course of action or inaction in a manner affecting trade or investment between the Parties." ${ }^{78}$ In paragraph 6 of Article 20.3, the Parties further recognize that "it is inappropriate to encourage trade or investment by weakening or reducing the protection afforded in their respective environmental laws. Accordingly, a Party shall not waive or otherwise derogate from, or offer to waive or otherwise derogate from, its environmental laws in a manner that weakens or reduces the protection afforded in those laws in order to encourage trade or investment between the Parties." ${ }^{\prime 9}$ These provisions demonstrate that environmental protection afforded in the parties' respective laws cannot be weakened or reduced to encourage trade or investment. This obligatory mandate will inevitably impose restrictions on trade and investment. It is thus evident that environment organizations can penetrate in and influence the international economic order extensively.

To be more specific, environment organizations expanded their functions in evaluating environmental performance. The parties have placed much hope on the voluntary mechanisms ${ }^{80}$ concerning the environmental protection and the improvement of criteria of evaluating environmental performance, believing that voluntary mechanisms can contribute to the achievement and maintenance of high levels of environmental protection and complement domestic regulatory measures. In paragraph 2(a) of Article 20.11, it stipulates

$7^{6}$ Text of Trans-Pacific Partnership Agreement, Chapter 20 Environment, Article 20.2 Objectives, para. 1.

77 Id., Article 20.3 General Commitments, para. 2, 3.

78 Id., para. 4 .

$79 \quad I d$., para. 6.

8o Voluntary mechanisms include, for example, voluntary auditing and reporting, marketbased incentives, voluntary sharing of information and expertise, and public-private partnerships. 
that "in accordance with its laws, regulations or policies and to the extent it considers appropriate, each party shall encourage the use of flexible and voluntary mechanisms to protect natural resources and the environment in its territory" 81 The parties shall also "encourage its relevant authorities, business and business organizations, non-governmental organizations and other interested persons involved in the development of criteria used to evaluate environmental performance, with respect to these voluntary mechanisms, to continue to develop and improve such criteria." ${ }^{22}$ This indicates that civil societies are expected to play an important role in environment-related matters and they are becoming a much more manipulative force on the governments of the respective parties.

In addition, environment organizations attempted to avail of the "trade sanctions" in the dispute settlement mechanism to legislate their "habits of the heart" so as to increase their power and influence. ${ }^{83}$ The parties to the TPP would be obligated to adopt, implement, and effectively enforce laws and regulations to fulfill their obligations under seven multilateral environmental agreements. In many FTAs do not include environment chapters. To the extent they are included, the language is in the nature of hortatory "best endeavor" commitments. ${ }^{84}$ However, the environmental provisions in the ТPP are enforceable under its dispute settlement mechanism and violations are subject to potential trade sanctions. ${ }^{85}$ Thus, the environment standards have been further strengthened in the TPP.

Like in NAFTA, the enforcement provisions of the TPP agreement also consisted of objective reviews of claimed violations, coupled with state-to-state consultations. The Parties establish an Environment Committee composed of senior government representatives, or their designees, of the relevant trade and environment national authorities of each Party responsible for the implementation of Chapter 20. ${ }^{86}$ The purpose of the Environment Committee is to oversee the implementation of Chapter 20 and its functions shall be to provide

81 Above n 76, Article 20.11 Voluntary Mechanisms to Enhance Environmental Performance, para. 2(a).

$82 \quad$ Id., para. $2(\mathrm{~b})$.

83 Colambato E. and J. Macey, The Decline of the Nation-State and Its Effects on Constitutional International Economic Law, 18 Cardozo Law Review 903 (1996).

84 See Du, above n 6o, at 423 .

85 David P. Vincent, The Trans-Pacific Partnership: Environmental Savior or Regulatory Carte Blanche?, Minnesota Journal of International Law, Vol. 23 (2014), at 25.

86 Above n 76, Article 20.19 Environment Committee and Contact Points, para. 2. 
a forum to discuss and review the implementation of Chapter 20 and to provide a forum to discuss and review cooperative activities under Chapter $20 .{ }^{87}$ During the fifth year after the date of entry into force of the TPP Agreement, the Environment Committee shall review the implementation and operation of Chapter 20 and undertake subsequent reviews at intervals to be decided by the Parties. ${ }^{88}$ In Article 20.20 of the TPP text, the procedures of Environment Consultations are provided; while in Article 20.22 and Article 20.23, higher levels of consultations are complemented by Senior Representative Consultations and Ministerial Consultations. If the consulting Parties have failed to resolve the matter under Article 20.20 (Environment Consultations), Article 20.21 (Senior Representative Consultations) and Article 20.22 (Ministerial Consultations) within 60 days after the date of receipt of a request under Article 20.20, or any other period as the consulting Parties may agree, the requesting Party may request consultations under Article 28.5 (Consultations) or request the establishment of a panel under Article 28.7 (Establishment of a Panel) ${ }^{89}$ Thus, disputes concerning environmental matters among the TPP parties can be settled accordingly and the enforcement of high-level environmental protection can be effectively guaranteed.

The reasons why the environment organizations are so powerful are closely linked to those maintaining the democratic politics in America. The U.s. middle class participated in politics through various associations (such as trade unions), and among the customs most important for maintaining democracy in America were the myriad civil voluntary associations in the country. ${ }^{90}$ The environment organizations are "only a single feature in the midst of the immense assemblage of associations in that country. Americans of all ages, all conditions, and all dispositions constantly form associations ... Wherever at the head of some new undertaking you see the government in France, or a man of rank in England, in the United States you will be sure to find an association." ${ }^{11}$ In a democracy, the voluntary associations as an intermediary layer of force between the ruling elites and the general public are necessary to prevent the abuse of power and to allow the general public to participate in

\footnotetext{
87 Id., Article 20.19 Environment Committee and Contact Points, para. 3(a) (c).

88 Id., Article 20.19 Environment Committee and Contact Points, para. 7(a) (c).

$89 \quad I d$., Article 20.23 Dispute Resolution, para. 1.

9o See Lal, above $\mathrm{n}$ 9, at 206.

91 De Tocqueville A., Democracy in America, Collins, London, 1835/1968, vol. II, chap. 5 .
} 
political processes. ${ }^{92}$ However, representative democracy restricted their capacity to influence politics. ${ }^{93}$

The U.s. middle class is the breeding ground for the myriad associations. In times of globalization, some of the associations have already become stronger and developed into large-scale non-governmental organizations, to which environment organizations belong. However, most of the causes they represent have failed to get democratic assent in the domestic politics of the Northern countries of their origin. Now they are trying to enforce their preferences by taking over international bureaucratic organizations. ${ }^{94}$ The environment organizations have even grown beyond national borders and are exerting direct influence on the international economic order. This backlash against globalization and trade liberalization cannot be neglected.

\subsection{Preliminary Conclusions}

An array of confusions and disorder appear when the United States is dominating the international economic order. These problems originated from America and were spread across the globe through the U.s. hegemon. The U.s. upper class has benefited from globalization and become much wealthier, while the most populous middle class have been losing their jobs and suffering from deteriorated living standards. The shuttle-shaped structure which keeps the U.s. society stable is now facing risks of collapse. When the upper class cannot curb the political appeals from the middle class, trade protectionism prevails. Thus, the problems faced with the U.s. middle class constitute the core issues thwarting globalization because they can influence the international economic order through the U.s. democratic politics and the myriad non-governmental organizations. The U.s. middle class has become the biggest obstacle for free trade and globalization.

The U.s. power in dominating the international economic order in the 21st century is experiencing a relatively decline to that of Britain in the 19th century, but the United States still remains the unique super power in today's world. The mightiness of the United States lies in its intellectual resources. However, its intellectual endowment is not powerful enough to adapt to the newly emerged international division of labor. The United States should prioritize tackling the problems faced with the U.s. middle class so as to clear

\footnotetext{
$92 \quad$ Ibid.

93 Burke E., Speech to the Electors of Bristol, in J. Payne (ed.), Select Works of Edmund Burke, vol. 4, Liberty Fund, Indianapolis, 1774/1999.

94 See Lal, above n 9, at 88.
} 
the way hampering globalization. To that end, particular emphasis should be placed on education and the full exertion of its intellectual resources. In that way, new breakthroughs in the field of science and technology can be expected to serve as the essential driving force for America to resume the domination of the international economic order. Though, it can also make some necessary reforms to its social, political and economic regimes. However, the western countries are embracing an era of "Philistine Politics", 95 in which there are no visionary leaders who can push those reforms. Together with the gradual and delicate transformation from representative democracy to participatory democracy ${ }^{96}$ the necessary changes seem even harder.

\section{$4 \quad$ China's Responsive Strategy}

In the interest of the United States, the promotion of free trade and globalization is also its incumbent responsibility. If the United States really wants to promote free trade across the globe, it should drop the principle of reciprocity and adopt the policy of unilateral free trade like Britain did in the nineteenth century. If it does so, the perplexity caused by the "spaghetti bowl" of PTAS will disappear and even the WTO may close down for good. ${ }^{97}$ Under the context where the United States has failed to unilaterally adopt the free trade policy, China as a developing country can but only adhere to classical liberalism under the extant conditions. China should insist on multilateralism, adopt flexible standards when negotiating FTAs, and implement the innovationdriven strategy.

\subsection{To Insist on Multilateralism}

Under the circumstances where the United States refused to unilaterally adopt free trade policy, Wто is still the best mechanism for trade liberalization. TPP belongs to PTAS which are discriminatory in essence, may increase the regulatory costs of the partners, ${ }^{98}$ and are far inferior to multilateralism in terms of promoting free trade globally. The higher standards on various non-tariff

\footnotetext{
95 Zheng Yongnian, The Decline of Political Wisdom and the Crisis of the International Order, Lianhe Zaobao, see http://www.zaobao.com/forum/views/opinion/story20160607 $-626122 /$ page/o/1, accessed on July 15, 2016.

96 The western notion of a liberal democracy is based on representative democracy. See Lal, above $\mathrm{n} 9$, at 210 .

$97 \quad I d .$, at 89.

98 Id., at $71^{-} 74$.
} 
issues have built discriminatory walls between the developed and major developing countries in the Asia-Pacific region, making the role of TPP on promoting free trade trivial. TPP cannot represent the best approach for free trade, either. The key whether a trade agreement can represent the template of trade agreement in the 21st century lies not in the high standards on the various non-tariff issues, but in the true realization of free trade without or with the least possible attachment of additional non-tariff issues. In the author's view, whichever conforms to the classical liberalism will be the best approach to promote free trade.

The continuance of the reform and opening-up program is a necessary condition to insist on multilateralism. As Nicolas has shown, since the adoption of its reform and opening-up program, China has undertaken a massive measures of unilateral trade liberalization even before it acceded to the WTO in 2001. From one of the most protected economies, China has become perhaps the most open country among the newly emerged market economies. ${ }^{99}$ The opening-up program has led to China's astonishing export and economic growth, making China the workshop of the world. However, the twenty-first century may not be dominated by China. Although China with its overall GDP surpassing Japan has become the world's second largest economy, China is still a developing country with a low rank in terms of per-capita income. What China fears most is not being boasted as a rising power and framed with the so-called "China Threat Theory" by the western countries, but rather China itself becoming extremely arrogant blindly because of the achievement in the past 40 years.

\subsection{To Adopt Flexible Standards When Negotiating FTAs}

Although China remains the world workshop in terms of the manufacturing industry, it faces such problems as increasing labor costs and severe environmental pollution. In the near future, we will definitely see that China will further strengthen the protection of IPRs, give great impetus to the construction of ecological civilization, ${ }^{100}$ and gradually enhance the protection of labor

99 See Lardy N., Trade Liberalization and Its Role in Chinese Economic Growth, Mimeo, IMF-NCAER conference on A Tale of Two Giants: India and China's Experience with Reform and Growth, New Delhi, November, 2003, at 3; see also Lardy N., Integrating China into the World Economy, Brookings Institution, 2002, Washington, D.C.

100 On September 7, 2013, President Xi Jinping addressed in Nazarbayev University, Kazakhstan. He pointed out that "gold mountains and silver mountains are what we want, but lucid waters and lush mountains are also what we want; we would prefer the latter to the former because lucid waters and lush mountains themselves are invaluable assets." This demonstrates the attitude and resolution of the Chinese government in promoting ecological civilization." 
rights. However, in face of the high-standard trade rules in TPP, China should not follow them recklessly but give due consideration to the status quo of its economic development and adopt flexible standards when negotiating FTAs.

The RCEP has taken a more flexible approach since it allows for special and differential treatment to its prospective member countries depending upon their state of development, needs, and requirements. ${ }^{101}$ The Guiding Principle of RCEP negotiations states: "taking into consideration the different levels of development of the participating countries, the RCEP will include appropriate forms of flexibility including provision for special and differential treatment, plus additional flexibility to the least-developed ASEAN Member States, consistent with the existing ASEAN+1 FTAS, as applicable."102 The FTAs negotiated by China and ASEAN are typically less ambitious than the TPP, narrower in their coverage of trade in goods and services, and having few WTO-plus provisions. ${ }^{103}$ The newly proposed RCEP should try to go beyond WTO commitments, by exploring commitments related to trade and investment in areas not covered, or only partly covered, by the WTO. Also, there is a need for the RCEP to take into account sensitivities and asymmetries that exist among the countries participating in the negotiations, rather than imposing a template that does not reflect adequately the realities of the positions expressed by the countries. ${ }^{104}$

In addition, the RCEP is less comprehensive in the coverage of issues than the TPP and has paid far less attention to non-trade issues. For example, environment, labor, and government procurement issues are not likely to be covered in the RCEP. ${ }^{105}$ In the RCEP, developing members are explicitly provided longer phase-out periods and required less-comprehensive commitments compared to developed members. The RCEP will provide flexibility and

101 Sanchita Basu Das, RCEP and TPP: Comparisons and Concerns, ISEAS Perspective, January 7 th, 2013, at 3 .

102 Guiding Principles and Objectives for Negotiating the Regional Comprehensive Economic Partnership (2012).

103 Ann Capling and John Ravenhill, Multilateralising Regionalism: What Role for the TransPacific Partnership Agreement? The Pacific Review, Vol. 24, at 555; Ka Zeng, Multilateral versus Bilateral and Regional Trade Liberalization: Explaining China's Pursuit of Free Trade Agreements (FTAs), 19 (66) Journal of Contemporary China 635 (2010), at 642.

104 See Du, above n 6o, at 425.

105 Yoshifumi Fukunaga, ASEAN's Leadership in the Regional Comprehensive Economic Partnership, Asia \& the Pacific Policy Studies, Vol. 2 (2014), No. 1, at 113. 
adjusting mechanisms in reaching the common ends, for instance allowing sensitive items to be left out of the negotiations. ${ }^{106}$

\subsection{To Implement the Innovation-Driven Strategy}

In the global production chain China has not taken a top position, although this situation is gradually changing and China is becoming more of a innovationoriented country. The level of China's technology development has already ranked among the best in developing countries. In some of the important fields of technology, China has been among the top rank in the world. However, China's overall level of technology development has not yet been high. The supporting capacity of technology has been insufficient for China's social and economic development. The contribution of technology to China's economic growth has been far inferior to that of developed countries. ${ }^{107}$ To break the bottleneck of China's economic development, to resolve the deeply rooted conflicts and problems therein, and to occupy a favorable position in the global production chain, the fundamental way out is to promote innovation, and the key is to rely on technology.

China needs to strengthen the international sci-tech cooperation comprehensively by combining the import and export of sci-tech achievements and proactively blending into the international innovation network. Moreover, China needs a grand innovation-oriented talent team that can bear risks and incentivize their enthusiasm for innovation. ${ }^{108}$ In the area of commerce, a batch of innovative enterprises that can transform sci-tech achievements into commodities are much needed because they are the key for China to occupy a favorable position in the global production chain before China converts itself from a big country to a powerful country economically.

In the nineteenth century, classical liberalism originated from Britain. Nearly all the countries across the globe had benefited from the LiEo under the Pax Britannia, and the world economy had obtained substantial development.

\footnotetext{
106 Ian F. Fergusson et al., The Trans-Pacific Partnership Negotiations and Issues for Congress, CRs Report for Congress R42694 (30 January 2015), at 7 .

107 The Propaganda Department of the Central Committee of the CPC, Reading Book of A Series of Important Speeches of President Xi Jinping, Xuexi Publishing House \& People's Publishing House, 1st ed., 2016, Beijing, at $15^{2}$.

108 Id., at 153.
} 
The United States, after replacing Britain as the leading power in the world, has never taken in the essence of classical liberalism. Rather, it regards international trade as a "zero sum game" and upholds "fair trade" through the international institution of wTo/GATT. From the British free trade to the U.S. fair trade, from the wTо to the fragmented PTAs, and from free trade to protectionism, classical liberalism has been gradually fading away, which reflects the relative decline of the U.s. dominant power. The high standards on the various non-tariff issues in the TPP have reached a new altitude against classical liberalism. And the contradiction between the U.s. upper and middle class has made the role played by TPP in promoting free trade and globalization trivial. In face of the high-standard trade rules in TPP, China should not follow them recklessly but give due consideration to the status quo of its economic development when negotiating FTAs in the future. Under the context where the United States has failed to unilaterally adopt the free trade policy, China as a developing country can but only adhere to classical liberalism under the extant conditions. To be specific, China should insist on multilateralism, let the market play a decisive role in the allocation of its resources and implement the innovation-driven strategy. 